\title{
CORRELATION BETWEEN KNOWLEDGE, ATTITUDE AND BEHAVIOUR TOWARDS RIVER POLLUTION
}

\author{
Norshahida Akma Alias \\ Faculty of Applied Social Science, Universiti Sultan Zainal Abidin, Malaysia. \\ (Email: norshahida3692@gmail.com)
}

Received date: 19-06-2019

Revised date: 14-07-2019

Accepted date: 14-07-2019

Published date: 11-09-2019

To cite this document: Alias, N. A. (2019). Correlation between Knowledge, Attitude and Behaviour towards River Pollution. International Journal of Modern Trends in Social Sciences, 2(9), 31-38.

DOI: $10.35631 /$ IJMTSS.29004

\begin{abstract}
Lately, environmental issues are seen as one of the serious issues plaguing the world's population detected. One issue is the pollution of the river. This study aimed to determine the relationship between knowledge and attitude toward the behaviour of river pollution. Research conducted the survey method through the use of questionnaires as instruments to collect data on knowledge, attitudes, and behaviour of river pollution. A total of 150 respondents participated in the study. The results showed that knowledge and attitude have a significant correlation with the behaviour of river pollution. Although both variables have seen significant relationships on knowledge there is a more powerful influence on behaviour than attitude pollution.
\end{abstract}

Keywords: Environmental Knowledge, Environmental Attitude, Environmental Behaviour, River Pollution

\section{Introduction}

Since environmental issues are seen as one of the serious issues plaguing the world's population detected. One of the issues is the river pollution. River pollution or water pollution means that changes the physical, thermal, chemical, biological, water to affect any beneficial use, causing a situation which is dangerous to public health and safety or to the wildlife and plants. The problem of river pollution is a serious concern in the event of an increase in the human population, causing dependence on water resources has also increased. With the population growth rate is expected to increase from 32.6million people in 2019 to 39 million in 2150 (Jabatan Penerangan Malaysia, 2019; Jabatan Perangkaan Malaysia, 2019). To date, the human dependence on water resources makes a significant contribution, particularly in terms of human life and national development. This is because adequate water supply to drive domestic needs, agriculture and irrigation, and hydroelectric power generation. 
River pollution problems we have to deal with today and future impacts of human behaviour as a result of human apathy on the environment (He, Hong, Liu, \& Tiefenbacher, 2011; Pedde, Figueiredo, Nunes, \& Prodanov, 2015). In this case, the attitude of people who are not responsible indirectly contributes to the improvement of environmental problems. Not only influenced by the attitude but this issue is closely related to lack of knowledge about the environment (Howard \& Charles Sturt University, 2000; Mohiuddin, Mamun, Syed, Masud, $\& \mathrm{Su}, 2018$ ). To avoid the problem of river pollution on an ongoing basis, the distribution of information on this issue should be intensified so that the public know in depth the issue of river pollution. This means that individuals need to take cognizance of the activities that can contribute to the pollution of the river. Ironically the better knowledge of the individual to the environment indirectly, forms a pro-environment behaviour (Karpudewan, Roth, \& Abdullah, 2015). Therefore, to influence the knowledge society to establish positive behaviours so people always need to be reminded about the environment for humans and the environment are interconnected. So, this study is to determine the relationship between knowledge and attitude toward the behaviour of river pollution.

\section{Literature Review}

\section{The study of the relationship between knowledge and environmental behaviour} Osman, Jusoh, \& Amlus (2014), conducting studies "Knowledge and Environmental Attitude Towards Pro-Environmental Behaviour: Undergraduate Business Students Perspective". How these two variables showed significantly correlated with $r=.693$.

Varoglu, Temel, \& Yilmaz (2018) conducted studies on the relationship between knowledge, attitude, and behaviour of students. The findings show that environmental knowledge has a poor relationship but significant correlation $(\mathrm{r}=0.21, \mathrm{p}=0.05)$ against environmental behaviour.

\section{The Study of the Relationship Between Attitudes and Environmental Behaviour}

Killbert (2000) in conducting studies on attitudes, behaviour, and knowledge as a component of environmental literacy and research-focused university students. The findings show the existence of a significant relationship between attitude and behaviour. However, a study conducted on students in grade 6 shows that there is a strong correlation while correlation medium for 12th-grade students.

Fah \& Sirisena (2014) conducted a study to examine the relationship between variables attitude and environmental behaviour as the environmental dimension of literacy. The findings showed that both variables are significant and moderate correlation exists.

Osman, Jusoh, \& Amlus (2014), conducting studies on "Knowledge and Environmental Attitude Towards Pro-Environmental Behaviour: Undergraduate Business Students Perspective". How these two variables are the attitude and behaviour show that there is a significant correlation with $\mathrm{r}=.629$

Hines, Hungerford, \& Tomera (1987) in conducting studies on a meta-analysis of environmental behaviour, the results showed a significant moderate correlation $r=.347$. The findings show that individuals tend to form positive attitude positive behaviours. 


\section{Environmental Knowledge}

Environment knowledge is defined as a branch of knowledge that is based on facts, concepts, and relationship with the environment (Mostafa, 2007). In summary, knowledge of the environment focuses on the individual whether or not to know about what is happening to the environment. Not only focused on the individual but it also brings the relationship to the environment, whether positive or negative impact. In addition, the responsibility of each individual is required to maintain a balanced environment for sustainable development.

In particular, environmental knowledge is classified into three categories: system knowledge, action-related knowledge and effectiveness knowledge. System knowledge related to the processes that occur in an ecosystem or knowledge about environmental issues (Frick, Kaiser, $\&$ Wilson, 2004) and factors causing damages to the environment (Kaiser, Roczen, \& Bogner, 2008). According to Siefer, Neaman, Salgado, Diez, \& Otto (2015) the dimensions of system knowledge are using two indicators namely, geography environment system knowledge and human-environment system knowledge. The geography environment system knowledge is about how ecosystems work related while the human-environment system knowledge is much emphasis on human action that can lead to environmental degradation (Siefer et al., 2015).

The second dimension is related to the knowledge that is the work done by humans to reduce activities that can have an impact on the environment (Siefer Et Al., 2015; Thorn \& Bogner, 2018). Indicators used on this dimension are action knowledge that is a more relevant action in addressing environmental problems (Strydom, 2009; Yang, Shi, \& Kuang, 2016).

The third dimension is the comparison of the effectiveness of knowledge involving different options or actions to implement decisions that are more favourable to the environment (Fremerey \& Bogner, 2014; Halkos, Gkargkavouzi, \& Matsiori, 2018). This dimension is the level of environmental knowledge of the highest where it can be beneficial to humans and the environment when an action is taken most effectives (niaura, 2013).

\section{Environmental Attitude}

Environmental attitude means an expression will find that one thing people liked or disliked, support or oppose a decision being implemented, and have different views either positively or negatively on individuals, objects, and events (Petty \& Brinol, 2010). In summary, definition focused more on individual assessments of the things that are in their environment. However, according to McIntyre \& Milfont (2015), environmental attitude is a collection of beliefs, and intentions to act on environmental issues. In this case, it's an individual adjustment in finding solutions to address environmental problems. The environmental attitude focuses on threedimension namely environmental worldview, environmental concerns and environmental commitments (Aminrad, Azizi, Wahab, Huron, \& Nawawi, 2010; Harun, Hock, \& Othman, 2011). The environmental worldview is a dimension that is based on attitude. This dimension is important as the variables that can affect the action on the environment. There are three indicators used in this dimension of which is a fragility of nature's balanced, limits to growth and human over (Furman, 1998; Nooney, Woodrum, Hoban, \& Clifforf, 2003). The second dimension is environmental concerns that refer to a certain attitude that can change individual behaviour towards the environment (Aprile \& Fiorillo, 2017). Dimension of environmental concerns highlighted three indicators that focused on the environment ecocentric, anthropocentric and apathy. For the third dimension of the environmental commitments established three indicators of satisfaction, alternatives, and investment (Boyd, 2014; Davis, Le, \& Coy, 2011). 


\section{Environmental Behaviour}

Environmental behaviour means behaviour that reduces negative impacts on the natural environment such as minimizing the use of resources and energy and reduces the use of toxic materials (Kollmuss \& Agyeman, 2002).

\section{Research Methodology}

This study was conducted through a survey using a questionnaire as an instrument to obtain information related to knowledge, attitudes and behaviour of river pollution. The study involved 150 respondents. The instrument used in this study involves four parts. Part A contains background information on the respondents' gender, age, and education level. Part B is on knowledge towards river pollution. This construct consists of 12 questions that are closely linked to the knowledge of the relationship between ecosystems, interactions between organisms, causes of environmental problems and effective measures that can reduce river pollution. Part $\mathrm{C}$ is on attitude towards the river pollution that consists of 13 questions associated with indicator fragility of nature balance, limit to growth and human over nature, anti-anthropocentrism, exemptionalism, eco-crisis, ecocentric, anthropocentric, apathy, egoistic, altruistic and biospheric. Variable of knowledge and attitudes act as independent variables. The last part is Part D which is on the behaviour of river pollution as well as acting as the dependent variable. Questions that have been documented on all three been constructed in the form of statements that should be selected according to a Likert scale of 5, which are strongly disagree, disagree, unsure, agree and strongly agree.

\section{Result and Data Analysis}

\section{Respondent Background}

Table 1 shows the distribution of respondents by gender. The table shows the majority of respondents involved in this study were male respondents with a total of 77 people or $51.33 \%$ while female respondents was 73 persons or $48.67 \%$

Table 1: Distribution of Information Respondents by Gender

\begin{tabular}{cccc}
\hline Demographic & Factor & Number & Percentage \\
\hline Gender & Male & 77 & $51.33 \%$ \\
& Female & 73 & $48.67 \%$ \\
\cline { 2 - 4 } & Total & 150 & $100.00 \%$ \\
\hline
\end{tabular}

Table 2 shows the distribution of respondents by age. The table below shows the majority of respondents surveyed under the age of 21 to 30 years i.e. a total of 93 people or $62.00 \%$. This means that the respondent is composed of youth in the productive age group.

Table 2: Distribution of Information Respondents by Age

\begin{tabular}{cccc}
\hline Demographic & Factor & Number & Percentage \\
\hline Age & 10 to 20 & 16 & $10.67 \%$ \\
& 21 to 30 & 93 & $62.00 \%$ \\
& 31 to 40 & 18 & $12.00 \%$ \\
& 41 to 50 & 3 & $2.00 \%$ \\
& 51 to 60 & 20 & $13.33 \%$ \\
\cline { 2 - 4 } & Total & 150 & $100.00 \%$ \\
\hline
\end{tabular}


Table 3 shows the distribution of respondents by the level of education. The majority of respondents involved in this study had a high school education level of a total of 55 people or $36.67 \%$

Table 3: Distribution of Respondents by Education Level

\begin{tabular}{cccc}
\hline Demographic & Factor & Number & Percentage \\
\hline Education Level & Diploma & 13 & $8.67 \%$ \\
& Degree & 34 & $22.67 \%$ \\
& Master & 2 & $1.33 \%$ \\
& Secondary School & 55 & $36.67 \%$ \\
& Primary School & 16 & $10.67 \%$ \\
& Certificates & 30 & $20.00 \%$ \\
\cline { 2 - 4 } & Total & 150 & $100.00 \%$ \\
\hline
\end{tabular}

Table 4 shows the analysis of the correlation coefficient knowledge and attitudes toward river pollution. The results show the strength of the relationship between knowledge toward behaviour of river pollution equal to 0.401 . The relationship between these two variables shows that there is a moderate relationship. As the value of $p$ in Table 5 show $<0.0001$ is smaller than 0.05 , hypothesis 1 successfully rejected. This shows there is a significant relationship between knowledge towards behaviour of river pollution.

Next, Table 4 shows the analysis of the variables attitude towards the behaviour of river pollution. The results show the strength of the relationship between attitudes toward the behaviour of river pollution equal to 0.315 . The relationship between these two variables shows that there is a weak relationship. As the value of $\mathrm{p}$ in Table 5 shows $<0.0001$ is smaller than 0.05 , hypothesis 2 successfully rejected. This shows there is a significant relationship between attitudes towards behaviour of river pollution.

Table 4: Analysis of Pearson Knowledge and Attitudes Toward Behavioral River

Pollution

\begin{tabular}{cccc}
\hline Variables & $\begin{array}{c}\text { The Behavior } \\
\text { Of River } \\
\text { Pollution }\end{array}$ & Knowledge & Attitude \\
\hline Behavior Of River Pollution & 1 & 0.401 & 0.315 \\
Knowledge & 0.401 & 1 & 0.451 \\
Attitude & 0.315 & 0.451 & 1 \\
\hline
\end{tabular}

Table 5: Analysis of Pearson (Value-P) Knowledge and Attitudes Toward Behavioral River Pollution

\begin{tabular}{cccc}
\hline Variables & $\begin{array}{c}\text { Behavior Of } \\
\text { River Pollution }\end{array}$ & Knowledge & Attitude \\
\hline The Behavior Of River Pollution & 0 & 0.000 & 0.000 \\
Knowledge & $<0.0001$ & 0 & $<0.0001$ \\
Attitude & $<0.0001$ & $<0.0001$ & 0 \\
\hline
\end{tabular}




\section{Discussion}

The findings show the existence of a moderate correlation between knowledge and behaviour of river pollution $(\mathrm{r}=0.401, \mathrm{p}=<0.0001)$. It shows individuals who have a high level of knowledge which plays an important role in contributing to the formation of positive behaviours. The findings of parallel studies conducted by Hines, Hungerford, \& Tomera (1987) on a meta-analysis related to environmental behaviour showed that the correlation between knowledge and behaviour of the environment is $r=.161$

So positive correlation indicates that the individual has a high level of knowledge on the issue of river pollution indirectly will form a responsible behaviour towards the environment.

The findings show the existence of a weak correlation between attitudes and behaviour of river pollution $(\mathrm{r}=0.315, \mathrm{p}=<0.0001)$. The findings of the parallel studies conducted by Kuhlmeier, Bergh, \& Lagerweij (1999) related to knowledge, attitude and behaviour of students in Holland found the significant correlation was weak $(r=.36)$. The findings of Fah $\&$ Sirisena (2014) also shows that there is a weak correlation between attitudes and behaviour as literacy environmental dimension $(\mathrm{r}=.224, \mathrm{p}=.010)$.

The findings show that individuals who have an optimistic attitude toward the issue of river pollution also contribute to positive behaviours.

\section{Conclusion}

Nowadays the issue of pollution has become one of the environmental issues faced by the community. This is because the relationship between humans and the environment are increasingly distressful. Thus, to minimize the impact of human activities on the environment we need to change the attitude of society advance and enhance environmental knowledge as well as to establish positive behaviours.

Knowledge and attitudes that make up a predictor of environmental behaviour directly (Karpudewan, Ismail, \& Roth, 2012). In this study, knowledge and attitudes related to the behaviour of river pollution. Collectively, the two variables act as factors that contribute to the formation of the behaviour of river pollution. Formation behaviour can occur in two ways, either positive or negative. If the individual has a piece of good knowledge and attitude on the issue of river pollution indirectly it would constitute behaviour towards keeping the river and vice versa.

\section{References}

Aminrad, Z., Azizi, M., Wahab, M., Huron, R., \& Nawawi, M. (2010). Environmental awareness and attitude among Iranian students in Malaysian universities. EnvironmentAsia, 3(SPECIAL ISSUE), 1-10. https://doi.org/10.14456/ea.2010.34

Aprile, M. C., \& Fiorillo, D. (2017). Water conservation behavior and environmental concerns: evidence from a representative sample of Italian individuals. Journal of Cleaner Production, 159, 119-129. https://doi.org/10.1016/j.jclepro.2017.05.036

Boyd, S. W. (2014). Further Development of a Model of Environmental Commitment. Illinois State University: Master Thesis.

Davis, J. L., Le, B., \& Coy, A. E. (2011). Building a model of commitment to the natural environment to predict ecological behavior and willingness to sacrific. Journal of Environmental Psychology,
https://doi.org/10.1016/j.jenvp.2011.01.00 
Fah, L. Y., \& Sirisena, A. (2014). Relationships between the knowledge, attitudes, and behavior dimensions of environmental literacy: A structural equation modeling approach using smartpls. Journal for Educational Thinkers, 5, 119-144.

Fremerey, C., \& Bogner, F. X. (2014). Learning about Drinking Water: How Important are the Three Dimensions of Knowledge that Can Change Individual Behavior? Education Sciences, 4, 213-228. https://doi.org/10.3390/educsci4040213

Frick, J., Kaiser, F. G., \& Wilson, M. (2004). Environmental knowledge and conservation behavior: Exploring prevalence and structure in a representative sample. Personality and Individual Differences, 37(8), 1597-1613. https://doi.org/10.1016/j.paid.2004.02.015

Furman, A. (1998). A Note On Environmental Concern In A Developing Country Result From An Istanbul Survey. Environment and Behavior, 30(4), 520-534. https://doi.org/0803973233

Halkos, G., Gkargkavouzi, A., \& Matsiori, S. (2018). Teachers' environmental knowledge and pro environmental behavior: An application of CNS and EID scales, (84505).

Harun, R., Hock, L. K., \& Othman, F. (2011). Environmental knowledge and attitude among student in Sabah. World Applied Sciences Journal, 14, 83-87.

He, X. (Elaine), Hong, T., Liu, L., \& Tiefenbacher, J. (2011). A comparative study of environmental knowledge, attitudes and behaviors among university students in China. International Research in Geographical and Environmental Education, 20(2), 91-104. https://doi.org/10.1080/10382046.2011.564783

Hines, J. M., Hungerford, H. R., \& Tomera, A. N. (1987). Analysis \& Synthesis of Research on Responsible Env Behavior.pdf. Journal of Environmental Education.

Howard, J., \& Charles Sturt University. (2000). Attitudes towards water conservation and salinity in the Albury Region. Johnstone Centre: Albury, N.S.W. : Johnstone Centre, Charles Sturt University, 2000.

Jabatan Penerangan Malaysia. (2019). Dasar Kependudukan Malaysia Ke Arah 70 Juta Penduduk. Retrieved January 10, 2019, from http://pmr.penerangan.gov.my/index.php/maklumat-kenegaraan/239-dasarkependudukan-malaysia-ke-arah-70-juta-penduduk.html

Jabatan Perangkaan Malaysia. (2019). Jam Populasi. Retrieved January 10, 2019, from https://www.dosm.gov.my/v1/

Kaiser, F. G., Roczen, N., \& Bogner, F. X. (2008). Competence Formation in Environmental Education: Advancing Ecology-Specific Rather Than General Abilities. Umweltpsychologie, 12(2), 56-70.

Karpudewan, M., Ismail, Z., \& Roth, W. (2012). Promoting pro-environmental attitudes and reported behaviors of Malaysian pre-service teachers using green chemistry experiments. Environmental Education Research, 18(3), 375-389. https://doi.org/10.1080/13504622.2011.622841

Karpudewan, M., Roth, W., \& Abdullah, M. N. S. Bin. (2015). Enhancing Primary School Students' Knowledge about Global Warming and Environmental Attitude Using Climate Change Activities. International Journal of Science Education, 37(1), 31-54. https://doi.org/10.1080/09500693.2014.958600

Killbert, N. . (2000). An analysis of the correlations between the attitude, behaviour, and knowledge components of environmental literacy in undergraduate university students. Master Thesis, University of Florida.

Kollmuss, A., \& Agyeman, J. (2002). Mind the Gap : Why Do People Act Environmentally and What Are The Barriers To Pro- Environmental Behavior? Environmental Education Research, 8(3), 239-260. https://doi.org/10.1080/1350462022014540 1 
Kuhlemeier, H., Bergh, H. Van Den, \& Lagerweij, N. (1999). Environmental Knowledge , Attitudes, and Behavior in Dutch Secondary Education. The Journal of Environmental Education, 30(2), 4-14. https://doi.org/10.1080/00958969909601864

McIntyre, A., \& Milfont, T. L. (2015). Who Cares ? Measuring Environmental Attitudes. In R. Gifford (Ed.), Research Methods for Environmental Psychology (1 edition, pp. 93114). Milton, QLD, Australia: Wiley-Blackwell.

Mohiuddin, M., Mamun, A. Al, Syed, F. A., Masud, M. M., \& Su, Z. (2018). Environmental Knowledge, Awareness, and Business School Students' Intentions to Purchase Green Vehicles in Emerging Countries. Sustainability, 10(5), 1534. https://doi.org/10.3390/su10051534

Mostafa, M. M. (2007). Gender differences in Egyptian consumers green purchase behaviour: the effects of environmental knowledge, concern and attitude. International Journal of Consumer Studies, 31(3), 220-229. https://doi.org/10.1111/j.1470-6431.2006.00523.x

Niaura, A. (2013). Using the Theory of Planned Behavior to Investigate the Determinants of Environmental Behavior among Youth. Environmental Research, Engineering and Management, 1(1), 74-81. https://doi.org/10.5755/j01.erem.63.1.2901

Nooney, J. G., Woodrum, E., Hoban, T. J., \& Clifforf, W. B. (2003). Environmental Worldview and Behavior: Consequences of Dimensionality in a Survey of North Carolinians. Environment \& Behavior, 35(6), 763-783. https://doi.org/10.1177/0013916503256246

Osman, N. H., Jusoh, M. ., \& Amlus, H. (2014). Exploring The Relationship Between Environmental Knowledge and Environmental Attitude Towards Pro-Environmental Behaviour: Undergraduate Business Students Perspective. American-Eurasian Journal of Sustainable Agriculture, 8(8), 1-4.

Pedde, V., Figueiredo, J., Nunes, M., \& Prodanov, C. (2015). Environment and society: the Sinos River Basin and public policies. Braz. J. Biol, 75(2), 128-136.

Petty, R. E., \& Brinol, P. (2010). Attitude Structure and Change Implications for Implisit Measures. In Handbook of Implicit Social Cognition: Measurement, Theory, and Applications (pp. 335-352). https://doi.org/10.1017/CBO9781107415324.004

Siefer, P. D., Neaman, A., Salgado, E., Diez, J. L. C., \& Otto, S. (2015). Human-environment system knowledge: A correlate of pro-environmental behavior. Sustainability, 7, 15510-15526. https://doi.org/10.3390/su71115510

Strydom, W. F. (2009). The impact of State-Of-Rivers reporting on people's attitudes towards river conservation: A case study of the Buffalo and Hartenbos \& Klein Brak catchments in South Africa. University of Stellenbosch : Master Thesis.

Thorn, C., \& Bogner, F. X. (2018). How Environmental Values Predict Acquisition of Different Cognitive Knowledge Types with Regard to Forest Conservation. Sustainability, 10(7), 2188. https://doi.org/10.3390/su10072188

Varoglu, L., Temel, S., \& Yilmaz, A. (2018). Knowledge, attitudes and behaviours towards the environmental issues: Case of Northern Cyprus. Eurasia Journal of Mathematics, Science and Technology Education, 14(3), 997-1004. https://doi.org/10.12973/ejmste/81153

Yang, N., Shi, Z., \& Kuang, Z. (2016). Why Green Consumption Behavior is "easier said than done"? - Evidence from China Market. International Journal of Business and Social Science, 7(7), 143-155. 